\title{
Invetigations of mechanical properties after dissimilar steels post-weld of Q345B steel
}

\section{Q345B çeliğinin benzer olmayan çeliklerle kaynağı sonrası mekanik özelliklerin incelenmesi}

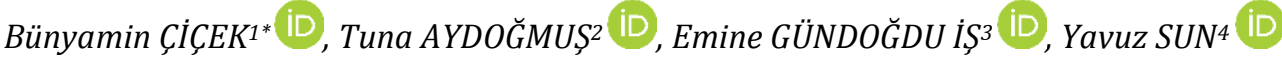

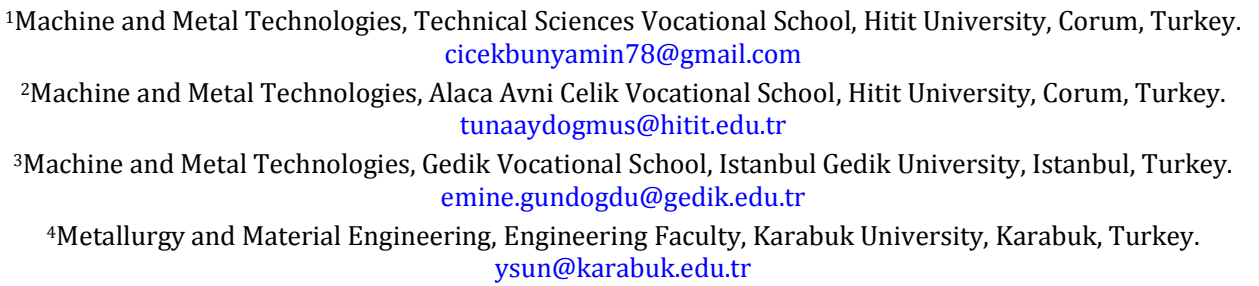

\section{Abstract}

In this study, it has been reported that Q345B steel combine with different steels using electric arc welding method and the mechanical properties were investigated. Produced by hot rolling processes, Q345B steel is a low-alloyed medium tensile strength and highly usable steel. The steel used contain less than 0.2\% carbon and less than 0.55\% silicon, chromium and nickel. In this study, Q345B steel generally used at low-pressure/temperature zones in thermal power plant (boiler wall etc.) is combined with $16 \mathrm{Mo} 3$ and P265GH steels. The Q345B steel is welded to make the mechanical properties easy to compare. After joining, specimens were collected from the welded areas and used in the preparation of mechanical and metallographic processes. In this process, all joints were subject to tensile, charpy, hardness and bending tests. In addition, the collection of macro images from welding were used in observation of transition zones which were operated. Electrodes with a basic character cover were used (E7018) as filler metal in the joining processes. All mechanical tests met the requirements of the relevant standards and all welds were identified as valid weld.

Keywords: Dissimilar alloys, Low carbon steel, Weld, Mechanical properties, Standard.

\section{Introduction}

Nowadays, a variety of structural steels is commonly used. Although all these steels are known as structural steel, problems arise during the welding processes. Different structural steels have to be used, especially in case of pressure changes and temperature changes. Choosing the appropriate electrode and welding method for joining non-chemically identical steels are the most important parameters. In thermal power plants, conditions such as temperature change are encountered. For example, Q345B steel is combined with different materials for use. The aim of this study is to determine and report the most suitable welding parameters for this steel [1]-[6].
Öz

Bu çalıșmada Q345B çeliğinin farklı çeliklerle elektrik ark kaynak yöntemi kullanarak birleștirilmesi ve mekanik özellikleri incelenmiştir. Sıcak haddeleme ișlemleri ile üretilmis olan 0345B çeliği düșük alașıml orta gerilmeli mukavemet değerlerine ve oldukça fazla kullanım alanına sahip bir çeliktir. \%0.2 den daha az karbon içeren bu celik $\% 0.55$ den daha az oranlarda silisyum, krom ve nikel ihtiva etmektedir. Bu çalışmada, genel olarak termik santrallerde (kazan duvarı gibi) düsük basınc ve düsük sıcaklık alanlarında kullanılan Q345B celiği; 16 Mo3 ve P265GH çelikleri ile birleștirilmiștir. Mekanik özelliklerinin karșılaștırmasının kolaylıkla yapılabilmesi için Q345B çeliği aynı zamanda kendisi ile de kaynak edilmiștir. Yapılan birleștirmeler sonrasında kaynaklı bölgelerden numuneler çıkartılıp mekanik ve metalografik işlemler için hazırlanmıștır. Bütün birleștirmeler sırasıyla çekme, çentik darbe, sertlik ve eğme testlerine tabi tutulmuşlardır. Bunların dıșinda geçis bölgelerini gözlemlemek için tüm kaynak dikişlerinden makro görüntüler alınmıştır. Birleștirme işlemlerinde dolgu metali olarak E7018 kalite bazik elektrot kullanılmıstır. Tüm mekanik testler ilgili standartların șartlarını sağlamış ve tüm kaynaklar geçerli bir kaynak olarak tanımlanmıștır.

Anahtar kelimeler: Benzer olmayan alașımlar, Düșük karbonlu çelik, Kaynak, Mekanik özellikler, Standart.

Welded joints, which do not contain the same value of elements close in terms of alloy, have resulted in the formation of a new active working area [7]. Taking into consideration the time in different solidification and microstructure formation of different alloys, inter-granular fractures are likely to occur and welding of different metals is possible only if this problem does not occur [7]-[10]. At this stage, many studies have been carried out in order to use the high-level properties of both alloys [9][12]. Firstly, it is important to combine $\mathrm{Cu}$ pipes with other alloys because of an increase in heat exchange and excellent thermal conductivity [12]. Secondly, the joining of Ni-based alloys with stainless steel types is indispensable for bonding type of power plants [10],[13]. Besides these properties, bonding structures are used to improve the percent elongation, toughness and precipitation conditions of the alloys [14]-[18].

${ }^{*}$ Corresponding author/Yazışılan Yazar 
Joining dissimilar alloys was aimed at increasing and/or improving different properties in different sectors, with the most important being the power plants [10],[19]. In the transition from high-pressure zones to low pressures or in high-temperature to low-temperature transfer zones, the welding of different alloys came to the fore [13],[20]. Q345B steel, which have these features and is frequently used in transition zones of power plants, has been the main subject of this study. Based on this idea, mechanical properties of Q345B steel welded with different steels were compared. Q345B steel is a steel with good comprehensive mechanical properties [2],[21]. This steel has a mechanical structure that exhibits precise plasticity, ductility and solubility [2],[3],[21],[22]. It is a type of steel, which is evaluated within the scope of structural steel and actively used in many welded manufacturing zones (bridges, marine structures, engineering structures, energy production structures, etc.) [2],[17],[18],[21],[22]. Finally, it is a type of steel used in pressure vessel or piping systems with low-pressure value and which could be subjected to stop and/or start cyclic loads [3],[21],[22].

In this study, Q345B steel was welded both itself and with $16 \mathrm{Mo} 3$ and P265GH. All other parameters where keep constant except for the counter materials. As a result, reports examining mechanical values of welding of Q345B steel with other steels were been produced.

\section{Materials and methods}

In this study, Q345B steel with 150x10x300 mm dimensions and $16 \mathrm{Mo}, \mathrm{P} 265 \mathrm{GH}$ steels with the same dimensions were being used. The chemical compositions of this material were determined by spectral analysis and shown in Table 1, respectively. The welding applications are made in the form of butt joint and 8 passes and the schematic view is given in Figure 1 (Root pass: R, Filler Pass: F, Cap Pass: C, and Back Gouning: Ro). The maximum temperature between passes 350 ${ }^{\circ} \mathrm{C}$ and no preheating is applied. The jointing process were completed by oscillating movement with $2.5 \mathrm{~mm}$ diameter basic electrode E-MO-B-22 (E7018) according to TS EN ISO 3580 standard. Certified welders according to TS EN ISO 96061 have completed the welds [23],[24].

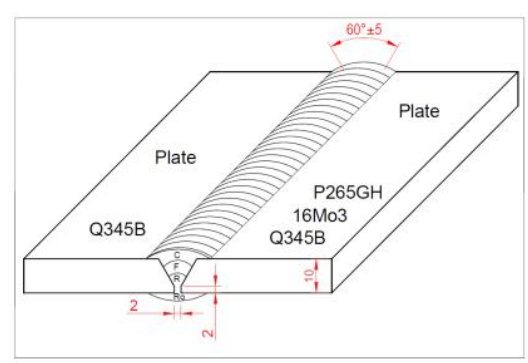

Figure 1. Schematic illustration for all joints ( $\mathrm{mm}$ ).

Data showing the chemical composition of the electrode used is show in Table 1. Carbon equivalence $\left(\mathrm{C}_{\mathrm{eq}}\right)$ have been calculated for each material and electrode and the values were interpreted. $\mathrm{C}_{\text {eq }}$ values calculated according to Japanese Welding Society (JWS) data [25]. The welding parameters were recorded separately for each pass. Accordingly, the welding parameters used during the joining of $\mathrm{Q} 345 \mathrm{~B}$ and $16 \mathrm{Mo} 3$, P265GH and Q345B steels are given in Table 2, respectively. In addition, the types and short names of the welded joints to be used in the article are shown in Table 3. Heat input was calculated using the parameters given in Table 2. The heat input for steel materials is an important parameter affecting the mechanical properties of the weld. Therefore, the heat input used the equation given in the Formula 1 below [4],[29].

$$
Q=k \frac{U x I}{v} \times 10^{-3}
$$

where; $Q=$ heat $\operatorname{input}(\mathrm{kJ} / \mathrm{mm}), \quad U=\operatorname{arc} \quad$ voltage(volt), $I=$ current $(\mathrm{amp}), v=$ weld speed $(\mathrm{mm} / \mathrm{s})$ and $k=$ welding efficiency coefficient. (Electric arc welding (SMAW) $k$ value according to the relevant standard $=0.8$ )

The heat input can generally be defined as the energy transferred per unit length in the weld metal. The excess heat input is directly related to the width of the heat-affected zone (HAZ). In this case, since the inter-pass temperature is determined as the preheating of the next pass, it significantly affects the characteristics of the weld metal. In other words, the rate of (or speed) heating and cooling of the materials to be welded determines the mechanical and metallurgical properties of the weld [13],[30]-[33].

Table 1. Chemical analyses for materials and filler metal.

\begin{tabular}{|c|c|c|c|c|}
\hline wt. \% & Q345B & 16Mo3 & P265GH & E7018-H4 \\
\hline $\mathrm{C}$ & 0.170 & 0.180 & 0.159 & 0.017 \\
\hline $\mathrm{Mn}$ & 1.520 & 0.520 & 1.178 & 1.406 \\
\hline$P$ & 0.015 & 0.025 & 0.013 & 0.014 \\
\hline$S$ & 0.003 & 0.010 & 0.007 & 0.006 \\
\hline $\mathrm{Si}$ & 0.250 & 0.350 & 0.223 & 0.471 \\
\hline $\mathrm{Al}$ & 0.034 & 0.025 & 0.044 & 0.001 \\
\hline $\mathrm{Cu}$ & 0.010 & 0.300 & 0.041 & 0.061 \\
\hline $\mathrm{Cr}$ & 0.060 & 0.030 & 0.026 & 0.029 \\
\hline $\mathrm{Ni}$ & 0.020 & 0.300 & 0.046 & 0.034 \\
\hline Mo & 0.003 & 0.270 & 0.003 & 0.004 \\
\hline V & 0.001 & 0.001 & 0.006 & 0.017 \\
\hline $\mathrm{Nb}$ & 0.001 & 0.001 & 0.001 & 0.003 \\
\hline $\mathrm{Ti}$ & 0.014 & 0.001 & 0.002 & 0.001 \\
\hline $\mathrm{N}_{(\mathrm{ppm})}$ & 26 & 29 & 47 & 80 \\
\hline $\mathrm{Fe}$ & \multicolumn{4}{|c|}{ Balance } \\
\hline $\mathrm{C}_{\mathrm{eq}}[1]-[3]$ & 0.258 & 0.257 & 0.230 & 0.110 \\
\hline
\end{tabular}

Table 2. Welding parameters.

\begin{tabular}{ccccc}
\hline \multirow{2}{*}{$\begin{array}{c}\text { Weld } \\
\text { Pass }\end{array}$} & Current & Volt & Weld Speed & Q Range \\
\cline { 2 - 5 } & $(\mathrm{I})$ & $(\mathrm{U})$ & $(\mathrm{mm} / \mathrm{s})(\mathrm{v})$ & $(\mathrm{kJ} / \mathrm{mm})$ \\
\hline $\mathrm{C}$ & $90-95$ & $22-24$ & 1.95 & $0.81-0.93$ \\
$\mathrm{~F}$ & $85-95$ & $22-24$ & 1.50 & $0.99-1.21$ \\
$\mathrm{R}$ & $70-75$ & $20-22$ & 0.71 & $1.57-1.85$ \\
Ro & $90-95$ & $22-24$ & 1.45 & $1.09-1.25$ \\
\hline
\end{tabular}


Table 3. Weld materials and abbreviations.

\begin{tabular}{|c|c|c|c|}
\hline \multicolumn{2}{|c|}{ Materials } & \multirow{2}{*}{ Filler Material } & \multirow{2}{*}{$\begin{array}{c}\text { Abbreviation } \\
\text { Name }\end{array}$} \\
\hline 1 & 2 & & \\
\hline \multirow{3}{*}{ Q345B } & Q345B & & QQ \\
\hline & 16Mo3 & E7018-H4 & QM \\
\hline & P265GH & & $\mathrm{QP}$ \\
\hline
\end{tabular}

Nondestructive Testing Methods (NDT) were applied to all samples after welding. Visual examination (VT), penetrant (PT) and radiography tests were performed by certified persons. Acceptance was applied at TS EN ISO 5817-B level [34] Samples that passed the NDT controls were subjected to mechanical tests adhering to the relevant standards. (Tensile Test (TS EN ISO 4136) [35], Bending Test (TS EN ISO 5173) [36], Impact Test (TS EN ISO 9016) [37], Hardness Test (TS EN ISO 9015-1) [38], Macrostructure Analysis (TS EN ISO 17639) [39])

\subsection{Tensile test}

Tensile testing was carried out with -Instron 5989- at room temperature and in accordance with the relevant standard ( $5 \mathrm{~mm} / \mathrm{min}$.). Schematic view of the test specimen is given in Figure 2. Before and after specimen preparation, instant etching with $5 \%$ Nital solution applied to the welded area of the specimen.

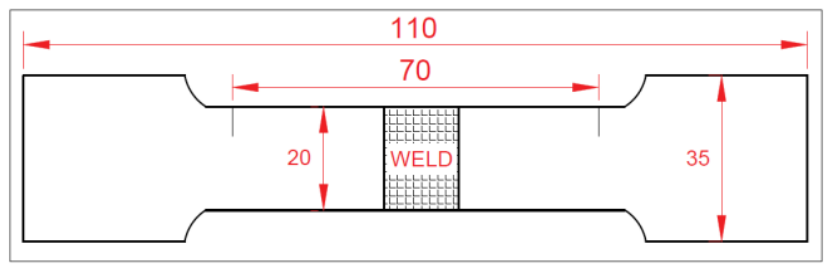

Figure 2. Tensile test specimen (mm) [35].

\subsection{Bending test}

Bending test is a mechanical test method for welded specimens. In this study, we separately prepared and tested specimens for root and cover passes for each weld. Schematic view of the prepared specimens is given in Figure 3. The A and B dimensions given in Figure 3 for the bending test were calculated taking into account the relevant standard [36] $(A=$ Distance Rollers, $\mathrm{B}=$ Force Diameter). The values of $\mathrm{A}$ and $\mathrm{B}$ shown in the figure were applied as 63 and $40 \mathrm{~mm}$ respectively and specimens were bent in " $U$ " type.

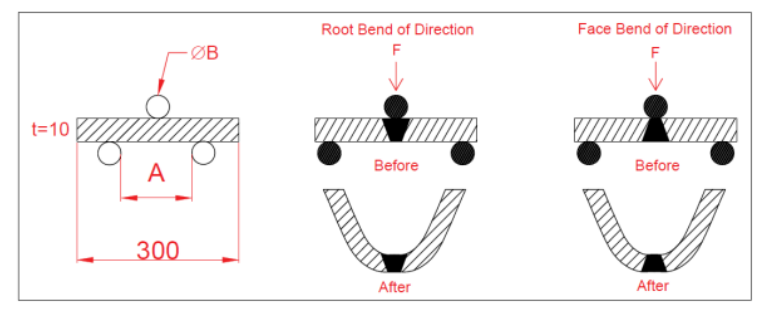

Figure 3. Bending test details and bending types ( $\mathrm{mm}$ ).

\subsection{Impact test (Charpy Type)}

Notch impact test is an important test method for welded joints. In this method the test temperature to $20^{\circ} \mathrm{C}$. Schematic illustration images of the test specimens are given in Figure 4. All specimens were being prepared in accordance with the relevant standard [37]. Impact tests were prepared as given in
Figure 4 and the weld metal 5\% Nital solution was etched. Thereafter, a $2 \mathrm{~mm}$ deep notch was made in the indicated areas [37]. Notches are prepared according to the standard with Blacks Charpy- manual arm apparatus. Charpy type crushing was performed on -Instron Impact $450 \mathrm{mpx}$ - model.

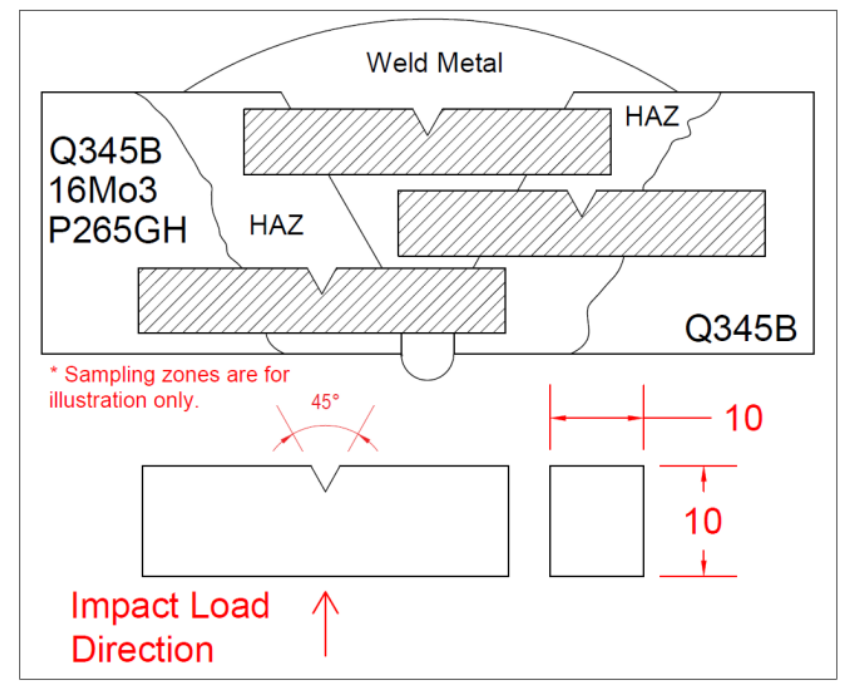

Figure 4. Impact tests for specimen types and test notch point $(\mathrm{mm})$.

\subsection{Hardness test (Vickers Type)}

Hardness test was conducted for each specimen by taking 3 lines (A-A, B-B and C-C) as shown in Figure 5. In the zones close to the melting (fusion) line, the number of test-conducted was increased and at least three tests were taken from each zone (HAZ, weld metal, and base metal) and a hardness graph was obtained. In order to ensure that the plastic deformation does not affect each other between the two test, an estimated min. $2.5 \mathrm{~mm}$ clearance was left [40]. Hardness measurements were performed on the -Qness Q10M- device using Vickers (HV) hardness unit under $1000 \mathrm{~g}$ load. The schematic view of the measuring lines is shown in Figure 5 [38].

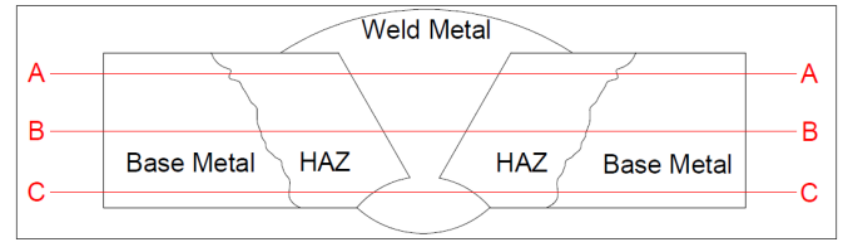

Figure 5. Hardness test lines and weld map.

\subsection{Macrostructure analysis}

The aim of this study was to compare mechanical properties of welded joints of Q345B steel with other steels, only macro structure analyses was examined as image analysis [39]. The specimen was prepared separately from all welded joints and macro etched. $5 \%$ Nital solution was used as etching solution and etching lasted for $10 \mathrm{~s}$ by dipping method. As a result, images of weld metal transition zones were taken and related evaluations are given in the conclusion section.

\section{Results and discussions}

The mechanical values of the welded materials examined as a result of welding of low carbon steels with different alloys were compared in this study. Welding of dissimilar materials is a difficult process due to different alloy ratios. In several studies, 
it has been observed that mechanical values in welding process of materials with different alloys give expected and good results [7],[8],[10],[14].

\subsection{Tensile test}

The comparative examination of the tensile test led to the result of the graph given in Figure 6. In addition, the actual photographs of the specimens with rupture because of tensile test are given in Figure 7. In the graph, the values obtained on the production certificates of the materials are shown with the results of the experiment. After the tensile tests have been apply to $\mathrm{QQ}, \mathrm{QM}$ and $\mathrm{QP}$ joints, breakage was respectively realize by Q345B, 16Mo3 and P265GH.

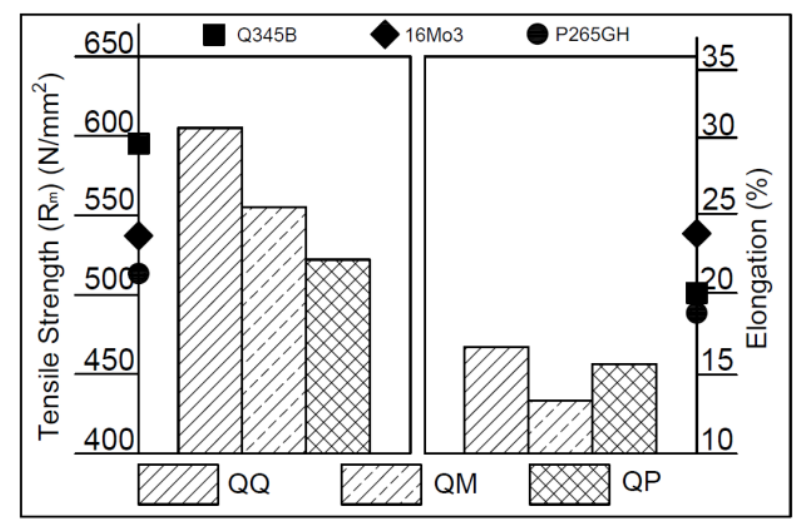

Figure 6. Certified and after-weld tensile strength-elongation values.

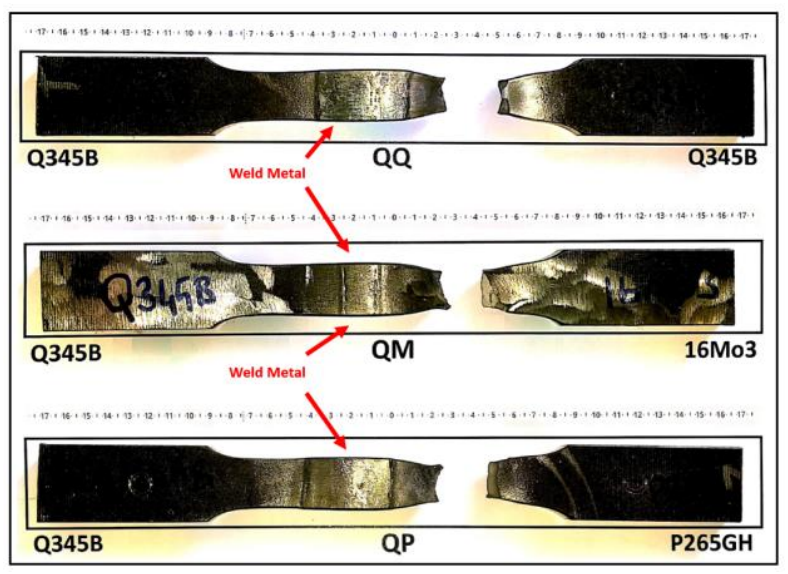

Figure 7. Tensile test specimens.

According to the tensile test results, the highest value in tensile strength was seen in QQ welded joint. The mean values of 604.5 $\mathrm{MPa}, 556.5 \mathrm{MPa}$ and $523.5 \mathrm{MPa}$ were respectively obtained in QQ, QM and QP specimens. After two successful tests from each specimen, deviation of maximum $7 \mathrm{MPa}$ was observed. Elongation values obtained during the tensile test were $16.7 \%$, $13.8 \%$ and $15.6 \%$. In the different tests of the specimens, the maximum deviation between the elongation values was $0.4 \%$. The highest percentage elongation was QQ joint.

Tensile strength increased in all joints according to the values taken from the break points formed in the HAZ except weldmetal (Figure 7). For example; in a manuscript by You et al., the tensile strength of Q345B steel was found to be 500-550 MPa [3]. From this point, the tensile strength in the QQ joint has increased about $5 \%$ because of rupture in HAZ. The increase in tensile strength of materials were exposed to some kind of recovery and tempering phase due to heat input effect in HAZ zone was an expected result [8],[13],[14],[17],[18],[35]. The same result was obtained for other welded joints. $16 \mathrm{Mo} 3$ and P265GH materials have a tensile strength higher than the certificate value. Because of the tests, an increase of approximately $5.5 \%$ and $4.5 \%$ was observed (QM and QP), respectively. The deformation amount increased with the effect of temperature effecting the HAZ and the tensile strength increased accordingly [41],[42].

\subsection{Bending test}

As a result of the bending test, welded materials were bent in "U" type. Twisting was done both by the cover and by the root. Because of penetrant test, one of the NDT methods, no cracks were detected on the surface. In the bending test, it can be concluded that the amount of elastic conversion permits a $\mathrm{U}$ type bending ratio, given that the crack condition is directly proportional to the amount of elongation. This explains why the weld metal exhibits at least as much torsional strength as the materials. Thus, weld metal is suitable for field use as basic materials [1],[4],[10],[36]. In addition, the actual photos of the specimens with bend because of test are given in Figure 8.

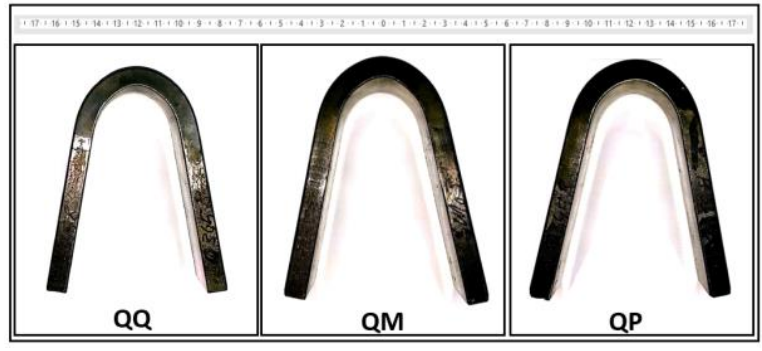

Figure 8. Bending test specimens

\subsection{Impact test (Charpy type)}

Specimens prepared according to the related standard gave an indication value as shown in Figure 9 (a) because of impact test applied with $400 \mathrm{kN}$ load impact $\left(-20^{\circ} \mathrm{C}\right)$. The figure shows the average fracture energy integer values (QQ-QM-QP) of the weld metal. In addition, the actual photographs of the specimens with the weld metal broken because of test are given in Figure 9(b). In addition, the results from all welded joints are given in Table 4.

Table 4. Impact test results.

\begin{tabular}{|c|c|c|c|c|c|c|c|c|}
\hline \multicolumn{3}{|c|}{$\mathrm{QQ}$} & \multicolumn{3}{|c|}{$\mathrm{QM}$} & \multicolumn{3}{|c|}{$\mathrm{QP}$} \\
\hline \multirow[t]{2}{*}{ Zone } & KV & $\begin{array}{l}\text { KV } \\
\text { Av. }\end{array}$ & Zone & KV & $\begin{array}{l}\text { KV } \\
\text { Av. }\end{array}$ & Zone & KV & $\begin{array}{l}\mathrm{KV} \\
\mathrm{Av} .\end{array}$ \\
\hline & 86 & & & 110 & & & 48 & \\
\hline \multirow[t]{3}{*}{$Q$} & 62 & 74 & M & 112 & 111 & $\mathrm{P}$ & 52 & 50 \\
\hline & 74 & & & 112 & & & 50 & \\
\hline & 34 & & & 113 & & & 31 & \\
\hline \multirow[t]{3}{*}{ HAZ } & 51 & 45 & HAZ & 145 & 122 & HAZ & 33 & 35 \\
\hline & 50 & & & 108 & & & 42 & \\
\hline & 88 & & & 48 & & & 117 & \\
\hline \multirow[t]{3}{*}{ WM } & 107 & 102 & WM & 64 & 51 & WM & 87 & 98 \\
\hline & 112 & & & 42 & & & 90 & \\
\hline & 32 & & & 30 & & & 31 & \\
\hline \multirow{3}{*}{ HAZ } & 59 & 49 & HAZ & 31 & 31 & HAZ & 34 & 33 \\
\hline & 55 & & & 31 & & & 32 & \\
\hline & 86 & & & 86 & & & 86 & \\
\hline \multirow[t]{2}{*}{ Q } & 62 & 74 & $Q$ & 62 & 74 & $\mathrm{Q}$ & 62 & 74 \\
\hline & 74 & & & 74 & & & 74 & \\
\hline
\end{tabular}

where in table; $Q=Q 345 B, M=16 M o 3, P=P 265 G H, W M=$ weld metal, $K V A v .=K V$ Average and all results joule unit. 


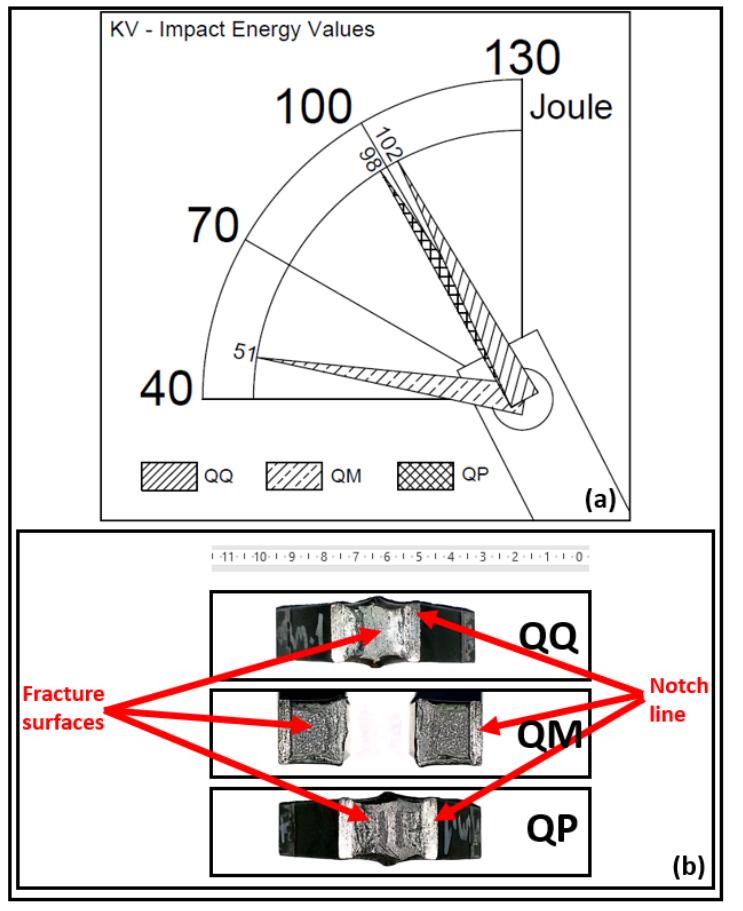

Figure 9. (a): Illustrated KV levels for weld metal. (b): Test specimens for charpy.

Generally, the formation of a coarse-grained zone in welding seams results in a brittle structure in the material. Therefore, the ductile-brittle characteristic of the rupture can be determined by the notch impact test. In this study, according to the impact notch test results applied to HAZs; is the fact that it has the ability to absorb heat when the material is differentiated [27],[31],[32].

In the QM and QP joints, the amount of KV on the HAZ side of the counter material (Q345B) was 30J; while in the QQ coupling, it increased to about 49J in the HAZ. From this point, while the KV level is high in HAZ in the weld (QQ) of two materials having the same alloy; the welding materials differ (QM and QP), the heat transfer coefficient is different; the amount of KV decreased. Since the amount of thermal conduction of the different elements in the chemical structure is different, the amount of heat input differs. This change can be observed in Table 4 with KV levels given [6],[7],[14],[26],[37]. As a result, Figure 9 (b) shows a broken QM showing a brittle structure with a lower KV level. QQ and QP specimens with high impact energy and therefore ductility were not separated.

Finally, it is stated in the related standard that no impact energy can show a value less than $27 \mathrm{~J}\left(-20^{\circ} \mathrm{C}\right)$ in any post-weld zone [43]. With this information, all welded joints have completed the standard requirements in terms of energy impact.

\subsection{Hardness test (Vickers type)}

The hardness values given in Figure 10 show the hardness distribution of different zones after welding. The main purpose of the hardness test in post-weld investigations is to monitor the trend direction of the hardness value in the transition from one region to another [38]. When all values are examined, it is seen that there is no sudden increase in the process. In addition, all welding zones meet the highest $350 \mathrm{HV}$ according to the relevant standard [43]. With this result, all welds (QQ, QM and $\mathrm{QP})$ can be considered valid according to the standard hardness test.

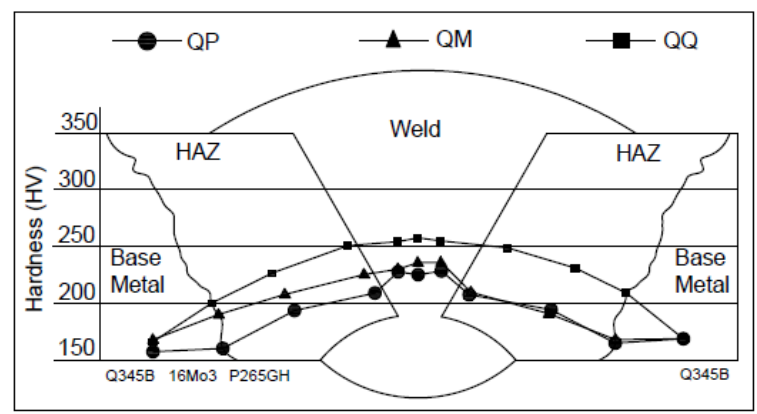

Figure 10. Graph illustrating the hardness test.

\subsection{Macrostructure analysis}

In all welding processes, both heat input and all parameters were kept under control. Adhering to this it is essential that all welds complete with full penetration. In order to investigate any porosity, gas gap, un-melted zone, slag residues (volumetric error), and all welded materials were subjected to macro inspection. When the pictures given in Figure 11 are examined, it is seen that the welds are completed with full penetration and the widths ratios of weld-HAZ are shown.

In the pictures, the welds HAZ and the main material are clearly monitored. When the HAZ widths are examined from this point of view, the HAZs in the QQ joint are prominent. The HAZ width on both sides proves with equal dimensions that the welding is done regularly. However, when using external steel with Q345B steel (16Mo3 and P265GH), both the width and color transitions of the HAZs differed. This is due to the difference in thermal conductivity of the materials influence by their chemical composition [6],[7],[10],[27]. In addition, as seen in the pictures, the materials were not exposed to a high heat input because the HAZs were narrower than the weld widths. When the weld structures seen as layered in the middle zone of the pictures are examined, no volumetric errors are seen.

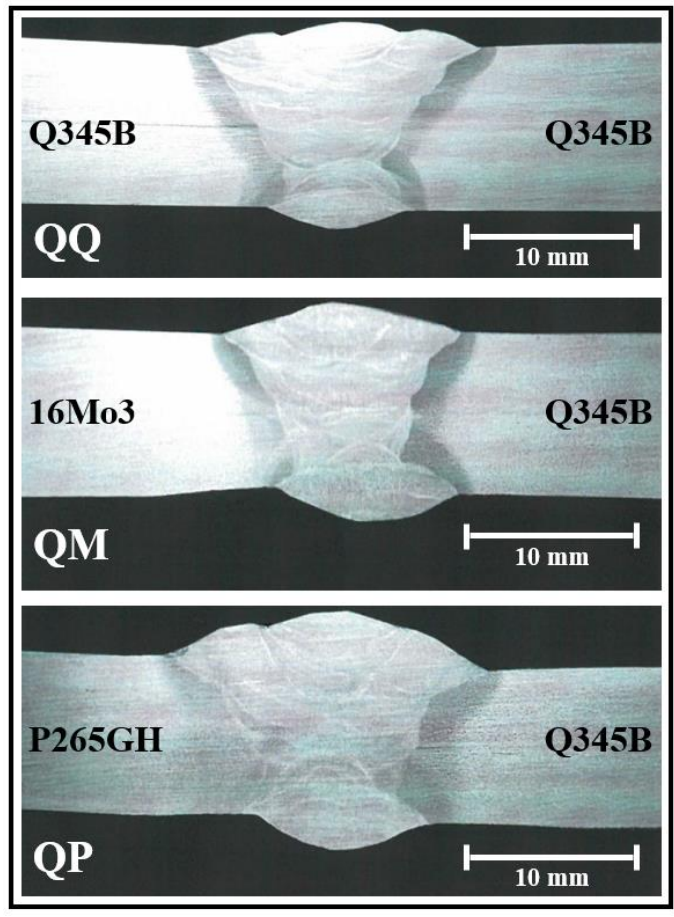

Figure 11. Macrostructure for all welds and materials. 


\section{Conclusions}

After welding Q345B steel with other dissimilar steels, mechanical properties and results were investigated in this study.

1 All welded materials were tested according to NDT results. All joins were successful, adhering to the standards concerning mechanical properties,

2 According to the tensile test results, breakage occurred after welding process by HAZ. Tensile test results showed an increase of about $5 \%$ compared to base material,

3 According to the bending test results, no crack initiation was detected in all $U$ type bended samples. The results were obtained by applying NDT methods,

4 After the impact test, the highest fracture energy of the weld metal occurred in QQ welding. In all welded zones, results above 27 Joules were obtained,

5 Hardness test results showed an increase in HAZ in all welds compared to base material. On the other hand, about $6 \%$ reduction was observed in the weld metal,

6 Macro examination of samples with all the joining; the formation of HAZ, welding, transition lines and pass was observed. No geometric and weld defects were observed.

\section{References}

[1] Guo J, Xu X, Jepson MA, Thomson RC. "Influence of weld thermal cycle and post weld heat treatment on the microstructure of MarBN steel". International Journal of Pressure Vessels and Piping, 174, 13-24, 2019.

[2] Hu X, Liu Y, Khan M, Wang Q. "High-Cycle Fatigue Properties and Damage Mechanism of Q345B Structural Steel". Strength of Materials, 49(1), 67-74, 2017.

[3] You X, Liu Y, Khan M, Wang Q. "Low cycle fatigue behaviour and life prediction of Q345B steel and its welded joint". Materials Research Innovations, 19(5), 1299-1303, 2015.

[4] Çiçek B, İş EG, Gümüș E, Topuz P. "The Effect of Welding Positions on the Weldability of X20CrMoV11-1 Steels". Hittite Journal of Science and Engineering, 5(1), 75-83, 2018.

[5] Salur E, Acarer M, Kabakçi F, Keskinkılıç S, Kumdalı Acar F, Çiçek B. "Microstructural and Mechanical Characterization of 9Cr-1Mo-1W Weld Metal". Hittite Journal of Science \& Engineering, 5(3), 203-208, 2018.

[6] Sopoušek J, Foret R. "More sophisticated thermodynamic designs of welds between dissimilar steels". Science and Technology of Welding and Joining, 13(1), 17-24, 2008.

[7] Soysal T, Kou S, Tat D, Pasang T. "Macrosegregation in dissimilar-metal fusion welding". Acta Materialia, 110, 149-160, 2016.

[8] Chen S, Huang J, Xia J, Zhang H, Zhao X. "Microstructural characteristics of a stainless steel/copper dissimilar joint made by laser welding". Metallurgical and Materials Transactions A, 44(8), 3690-3696, 2013.

[9] Magnabosco I, Ferro P, Bonollo F, Arnberg L. "An investigation of fusion zone microstructures in electron beam welding of copper-stainless steel". Materials Science and Engineering: A, 424(1-2), 163-173, 2006.

[10] Omar A. "Parameters on Hard Zone Dissimilar Metal Welds". Welding Journal, 1998, 86-93, 1998.
[11] Asai S, Ogawa T, Ishizaki Y, Minemura T, Minami H, Iyazaki SM. "Application of plasma MIG hybrid welding to dissimilar joints between copper and steel". Welding in the World, 56(1-2), 37-42, 2012.

[12] Mai T, Spowage A. "Characterisation of dissimilar joints in laser welding of steel-kovar, copper-steel and copperaluminium". Materials Science and Engineering: $A$, 374(1-2), 224-233, 2004.

[13] Ramkumar KD, Krishnan SR, Ramanand R, Logesh S, Satyandas T, Ameer A, Arivazhagan N. "Structureproperty relationships of PCGTA welds of Inconel X750 in as-welded and post-weld heat treated conditions-A comparative study". Journal of Manufacturing Processes, 20, 1-14, 2015.

[14] Hosseini HS, Shamanian M, Kermanpur A. "Microstructural and weldability analysis of Inconel617/AISI 310 stainless steel dissimilar welds". International Journal of Pressure Vessels and Piping, 144, 18-24, 2016.

[15] Rajani HZ, Mousavi SA, Sani FM. "Comparison of corrosion behavior between fusion cladded and explosive cladded Inconel 625/plain carbon steel bimetal plates". Materials \& Design, 43, 467-474, 2013.

[16] Srikanth A, Manikandan M. "Development of welding technique to avoid the sensitization in the alloy 600 by conventional Gas Tungsten Arc Welding method". Journal of Manufacturing Processes, 30, 452-466, 2017.

[17] Jafarzadegan M, Abdollah-Zadeh A, Feng A, Saeid T, Shen J, Assadi H. "Microstructure and mechanical properties of a dissimilar friction stir weld between austenitic stainless steel and low carbon steel". Journal of Materials Science \& Technology, 29(4), 367-372, 2013.

[18] Jafarzadegan M, Feng A, Abdollah-Zadeh A, Saeid T, Shen J, Assadi H. "Microstructural characterization in dissimilar friction stir welding between 304 stainless steel and st37 steel". Materials Characterization, 74, 28-41, 2012.

[19] Yang L, Shi G, Zhao M, Zhou W. "Research on interactive buckling behavior of welded steel box-section columns". Thin-Walled Structures, 115, 34-47, 2017.

[20] Anant R, Dahiya JP, Agrawal B, Ghosh P, Kumar R, Kumar S, Kumar K. "SMA, GTA and P-GMA dissimilar weld joints of $304 \mathrm{LN}$ stainless steel to HSLA steel; Part-1: thermal and microstructure characteristics". Materials Research 2018. https://iopscience.iop.org/article/10.1088/20531591/aad403.

[21] Han Q, Guo Q, Yin Y, Xing Y. "Fatigue performance of butt welds between cast steel joint and steel tubular members". Fatigue \& Fracture of Engineering Materials \& Structures, 40(4), 642-651, 2017.

[22] Han Q, Guo Q, Yin Y, Xing Y. "Fatigue behaviour of G20Mn5QT cast steel and butt welds with Q345B steel". International Journal of Steel Structures, 16(1), 139-149, 2016.

[23] International Organization for Standardization. "Qualification testing of welders - Fusion welding - Part 1: Steels". Vernier, Geneva, Switzerland, TS EN ISO-9606-1, 2017.

[24] International Organization for Standardization. "Welding Consumables-Covered Electrodes for Manual Metal Arc Welding of Creep-Resisting Steels-Classification". Vernier, Geneva, Switzerland, TS EN ISO-3580, 2017. 
[25] (JWS) JWS. "Calculation software of welding". 2011 Available $\quad$ From. http://wwwit.jwes.or.jp/weld_simulator/en/cal1.jsp (18.04.2019).

[26] Winterton K. "Weldability prediction from steel composition to avoid heat-affected zone cracking". Welding Journal, 40(6), 253-258, 1961.

[27] Lancaster JF, Metallurgy of welding. $6^{\text {th }}$ ed. Cambridge, England, Woodhead Publishing, 1999.

[28] ASTM International. "Standard Specification for General Requirements for Rolled Structural Steel Bars, Plates, Shapes, And Sheet Piling". West Conshohocken, PA, USA, A6/A6M-11, 2011.

[29] International Organization for Standardization. "WeldingRecommendations for Welding of Metallic Materials-Part 1: General Guidance for arc Welding". Vernier, Geneva, Switzerland, TS EN ISO-1011-1, 2010.

[30] Liskevych 0, Scotti A. "Determination of the gross heat input in arc welding". Journal of Materials Processing Technology, 225, 139-150, 2015.

[31] Gadallah R, Osawa N, Tanaka S, Tsutsumi S. "Critical investigation on the influence of welding heat input and welding residual stress on stress intensity factor and fatigue crack propagation". Engineering Failure Analysis, 89, 200-221, 2018.

[32] Gupta SK, Raja AR, Vashista M, Yusufzai MZK. "Effect of heat input on microstructure and mechanical properties in gas metal arc welding of ferritic stainless steel". Materials Research $\quad 2018$. https://iopscience.iop.org/article/10.1088/20531591/aaf492.

[33] İpekoğlu G, Küçükömeroğlu T, Aktarer SM, Sekban DM, Çam G. "Investigation of microstructure and mechanical properties of friction stir welded dissimilar St37/St52 joints". Materials Research Express, 2019. https://iopscience.iop.org/article/10.1088/20531591/aafb9f.

[34] International Organization for Standardization. "WeldingFusion-Welded Joints in Steel, Nickel, Titanium and Their Alloys (Beam Welding Excluded)-Quality Levels for Imperfections". Vernier, Geneva, Switzerland, TS EN ISO$5817,2014$.
[35] International Organization for Standardization. "Destructive tests on welds in metallic materialsTransverse tensile test". Vernier, Geneva, Switzerland, TS EN ISO-4136, 2013.

[36] International Organization for Standardization. "Destructive Tests on Welds in Metallic Materials-Bend Tests". Vernier, Geneva, Switzerland, TS EN ISO-5173, 2010.

[37] International Organization for Standardization. "Destructive Tests On Welds İn Metallic Materials - Impact Tests-Test Specimen Location, Notch Orientation and Examination". Vernier, Geneva, Switzerland, TS EN ISO9016, 2012.

[38] International Organization for Standardization. "Destructive Tests on Welds in Metallic MaterialsHardness Testing-Part 1: Hardness Test on Arc Welded Joints". Vernier, Geneva, Switzerland, TS EN ISO-9015-1, 2011.

[39] International Organization for Standardization. "Destructive Tests on Welds in Metallic MaterialsMacroscopic and Microscopic Examination of Welds". Vernier, Geneva, Switzerland, TS EN ISO-17639, 2014.

[40] Shahdad SA, McCabe JF, Bull S, Rusby S, Wassell RW. "Hardness measured with traditional Vickers and Martens hardness methods". Dental Materials, 23(9), 1079-1085, 2007.

[41] Ho H, Chung K, Liu X, Xiao M, Nethercot D. "Modelling tensile tests on high strength S690 steel materials undergoing large deformations". Engineering Structures, 192, 305-322, 2019.

[42] Chen C, Chiew S-P, Zhao M-S, Lee C-K, Fung T-C. "Welding effect on tensile strength of grade S690Q steel butt joint". Journal of Constructional Steel Research, 153, 153-168, 2019.

[43] International Organization for Standardization. "Specification and Qualification of Welding Procedures for Metallic Materials-Welding Procedure Test-Part 1: Arc and Gas Welding of Steels and Arc Welding of Nickel and Nickel Alloys". Vernier, Geneva, Switzerland, TS EN ISO15614-1, 2017 